$\underline{\text { Research Articles }}$

\title{
Evaluating interventions to reduce child marriage in India
}

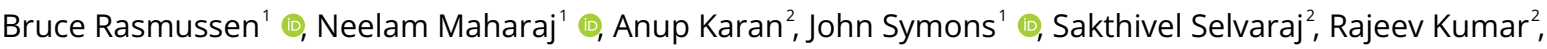 \\ Margarita Kumnick ${ }^{1}$, Peter Sheehan $^{1}$ (D) \\ ${ }^{1}$ Victoria Institute of Strategic Economic Studies, Victoria University, Melbourne, Victoria, Australia, ${ }^{2}$ Public Health Foundation of India, New Delhi, \\ India \\ Keywords: education interventions, investment, cost-benefit analysis, india, child marriage \\ https://doi.org/10.29392/001c.23619
}

\section{Journal of Global Health Reports}

Vol. 5, 2021

\begin{abstract}
Background
This paper estimates the costs and benefits of investing in education interventions and specific child marriage programs to reduce child marriage in India. Child marriage in India remains highly prevalent despite considerable progress in the last decade or more, associated, in particular, with a decline in poverty. The economic consequences of the COVID 19 pandemic are likely to reverse these gains, meaning that the interventions to reduce child marriage evaluated in this paper assume even greater importance.
\end{abstract}

\section{Methods}

A literature search to identify interventions with costs and estimates of impact on reduction in child marriage for India, and other low and middle income countries was conducted. The costs and effectiveness of the interventions were modelled for India, and economic benefits of reducing school dropout rates and increasing secondary school completions were estimated. The ratio of the economic benefits to the intervention costs estimated gave the benefit-cost ratio.

\section{Results}

The interventions resulted in an average benefit-cost ratio of 16.8. The interventions are projected to decrease the estimated marriage rate for girls aged 15-17 years for India from an estimated rate of $16.4 \%$ in 2020 by 7.5 percentage points by 2050 , with education interventions targeting increased attendance being the larger factor. By 2030, the proportion of girls completing school is estimated to increase by 13 percentage points and productivity to have increased by $16.4 \%$.

\section{Conclusions}

The results indicate substantial economic and social gains to reducing child marriage by interventions that decrease school dropout rates, increase secondary school completions for girls, and address some of the broader social and cultural disadvantages they face in India. This has significant implications not only for their health, but also for the quality of the available economic opportunities and the possibility of attaining Sustainable Development Goal 5.

Child marriage (CM) is defined as a legal or customary union that occurs before the age of 18 . In India, the minimum legal age of marriage is 18 for girls and 21 for boys. The Prohibition of Child Marriage Act, 2006 has closed loopholes which allowed $\mathrm{CM}$ and has made it a punishable offence. ${ }^{1}$ India is party to a range of international conventions outlawing child marriages, including several UN human rights conventions including the Convention on Consent to Marriage, Minimum Age for Marriage, and Registration of Marriages (1962). The accepted measure of the prevalence of CM is the proportion of women aged 20-24 who were married prior to $18 .^{2}$ This is generally higher than the proportion of girls aged 18 or under, married at a particular point in time, due to underreporting for girls below the legal age of marriage. ${ }^{3}$

In part, because of its size and high prevalence in a number of poorer states, India, in spite of the laws, has the highest number of child marriages in the world, about 1.5 million each year. ${ }^{4}$ However, CM in India has fallen significantly from $47 \%$ in $2005-06$ to $27 \%$ in $2015-16 .^{5-7}$ The decline in CM is closely associated with improvements in girls' education, transition of households to an improved standard of living and a decrease in average household size. ${ }^{8,9}$ Some of the decline may also be due to the number of interventions and government programs, even though few have been appropriately evaluated. The serious economic impact of the COVID 19 pandemic on India is likely to reverse these favourable trends in child marriage. 
While a complex range of factors contribute to the continuing practice of $\mathrm{CM}$, the most important are:

- poverty, ${ }^{2,10}$ the average CM rate is $63 \%$ in the lowest quintile, whereas it is $10 \%$ in the highest. In Jumui in Bihar, the CM rate is $81 \%$ in the lowest quintile; ${ }^{11}$

- social and cultural norms, ${ }^{2,9,12-14}$ such as the practice of dowry; ${ }^{9}$ and

- truncated educational opportunities, ${ }^{9,11,15}$ girls discontinue education after marriage, mainly due to pressure from community, lack of permission from inlaws, and increasing household responsibilities and financial burden. ${ }^{15}$

There are significant differences in CM rates between the Indian states. As indicated, the reasons are complex, but a number, such as poverty and educational outcomes, are reflected in gross state product (GSP). Figure 1 shows the strong association between CM prevalence and GSP per capita in Indian states.

The theory of change ${ }^{16,17}$ on which our modelling framework is based, is that girls at risk of marriage benefit from improved educational and economic opportunities as alternatives to CM. The economic benefits of reduced CM arise from more productive employment opportunities because of improved education outcomes. The interventions to improve education outcomes are those designed to keep girls at school, reduce the dropout rate and extend the time at school to at least secondary school completion. These have the effect of delaying CM. Other interventions are aimed directly at reducing CM. By delaying marriage, these interventions help keep girls at school. These relationships are illustrated in Figure 2.

The aims of this paper are to identify the most effective interventions to reduce child marriage, to estimate their cost and impact for the case of India, and, using existing models ${ }^{18-20}$, to estimate the benefit-cost ratio for their application to India and their potential impact on CM.

\section{METHODS}

\section{INTERVENTIONS}

Of the interventions considered, three have direct impacts on $\mathrm{CM}$ rates, while four have indirect impacts through the effect of educational interventions on school attendance, and hence on CM rates (Figure 2). We estimate the impact of reduced $\mathrm{CM}$ on educational outcomes, notably early dropout, years of schooling and completion of secondary schooling. We also estimate the economic benefit of better educational outcomes (such as higher productivity and access to better employment), leading to higher levels of gross domestic product (GDP) per capita. The results are brought together in a cost-benefit analysis.

Evidence of the costs and effectiveness of specific CM interventions was sought through a literature search of peer reviewed articles and grey literature (see Figure 3). The peer-reviewed literature search for articles is an extension of the search conducted in Rasmussen et al. ${ }^{21}$ Web of Science and PubMed were searched from 2006 to 2020 (English articles only). The terms were varied, with the initial search (child marriage OR girl marriage OR early marriage) and

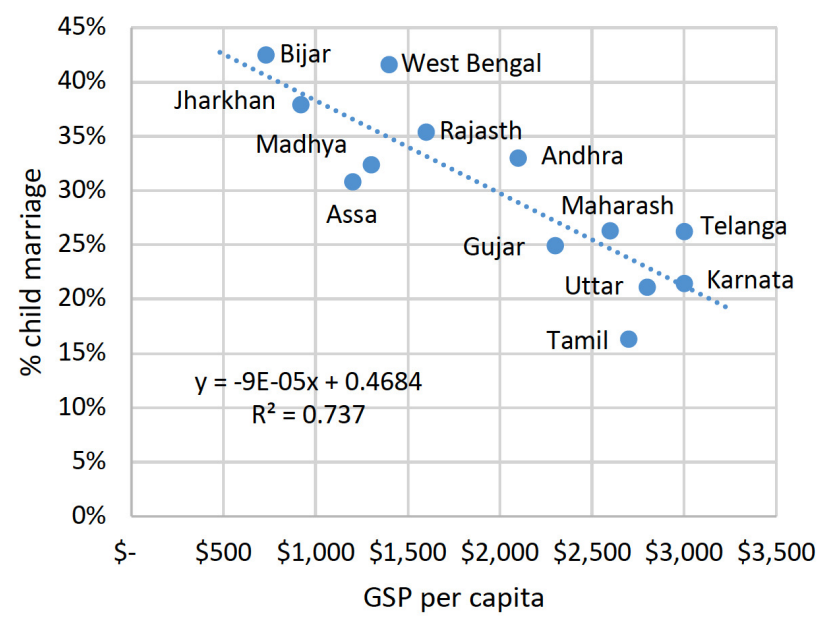

Figure 1. Association between child marriage prevalence and GSP per capita, Indian states, 2016.

(reduc* OR prevent*) resulting in 1456 articles in Web of Science, and 2012 articles in PubMed. These results were refined to (impact* OR intervention* OR trial* OR evaluation*) resulting in 562 articles in Web of Science and 777 in PubMed, totaling 1339 articles. The two sets were combined in Endnote (Clarivate Analytics, version x9.3), and $370 \mathrm{du}-$ plicates were removed, leaving 949 articles. The titles and abstracts of these were reviewed and 21 full-text articles were chosen for the assessment.

A grey literature search for non peer-reviewed literature and relevant reports was conducted in Google Scholar, university library catalogs, and websites of relevant agencies, in particular international agencies (e.g. World Bank, UNICEF, UNFPA, Population Council) and research centers. We specifically sought evidence from the Indian sub-continent. Fifty-five reports were downloaded and investigated for intervention results or impact.

Citations in relevant peer-reviewed journal articles and grey literature were hand searched for further relevant literature. A final set of 3 journal articles and 16 reports were selected for consideration in the modeling because of their relevance to interventions and impact on child marriage (see Table 1).

Malhotra et al. ${ }^{13}$ identified five main effective strategies that included: life skills, community mobilisation, education incentives, conditional economic incentives and legal framework. Kalamar et al. ${ }^{22}$ ranked interventions according to their detail, rigor, design and included impact measurement, randomization, and pre and post comparisons. From Table 1, we selected intervention studies, with a preference for those from India, that included cost and effectiveness estimates and which met Kalamar et al.'s ${ }^{22}$ criteria and conformed to Malhotra et al.'s ${ }^{13}$ framework. Where there were no available data for India, and where possible, we drew on evidence from studies conducted in other countries. A more recent review of interventions by Malhotra and Elnakib, ${ }^{23}$ broadly confirmed the selection of interventions used in this study. This included life skills training, conditional asset transfers to delay marriage, supply-side education interventions and the creation of female-focused employment 


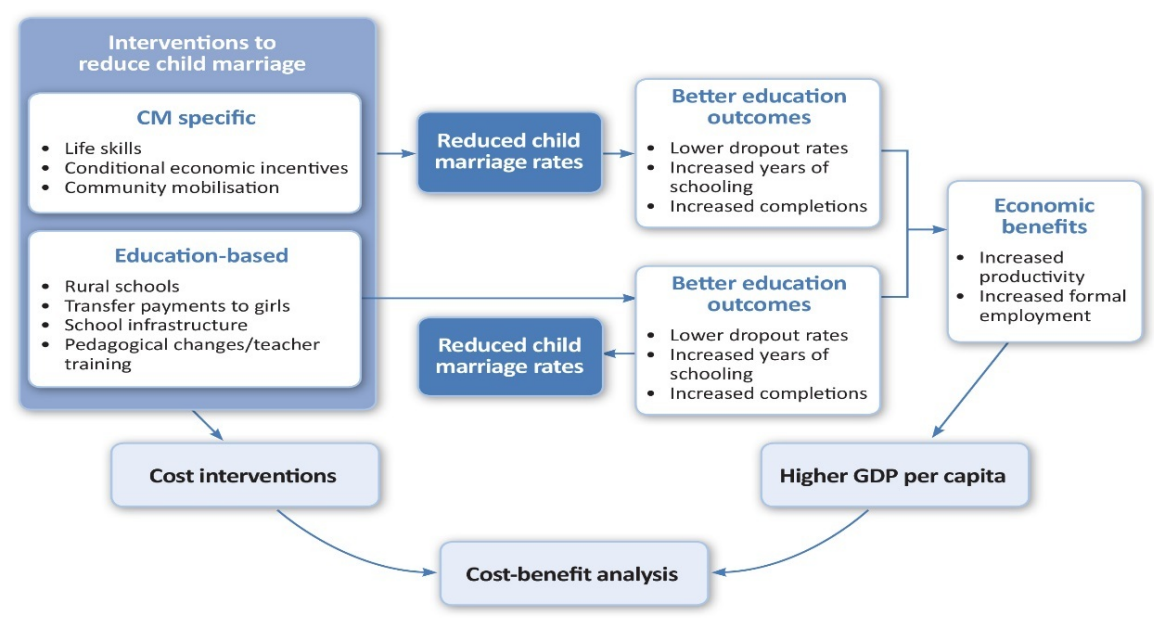

Figure 2. Modelling framework, estimating the benefit-cost ratios for the interventions to reduce child marriage.

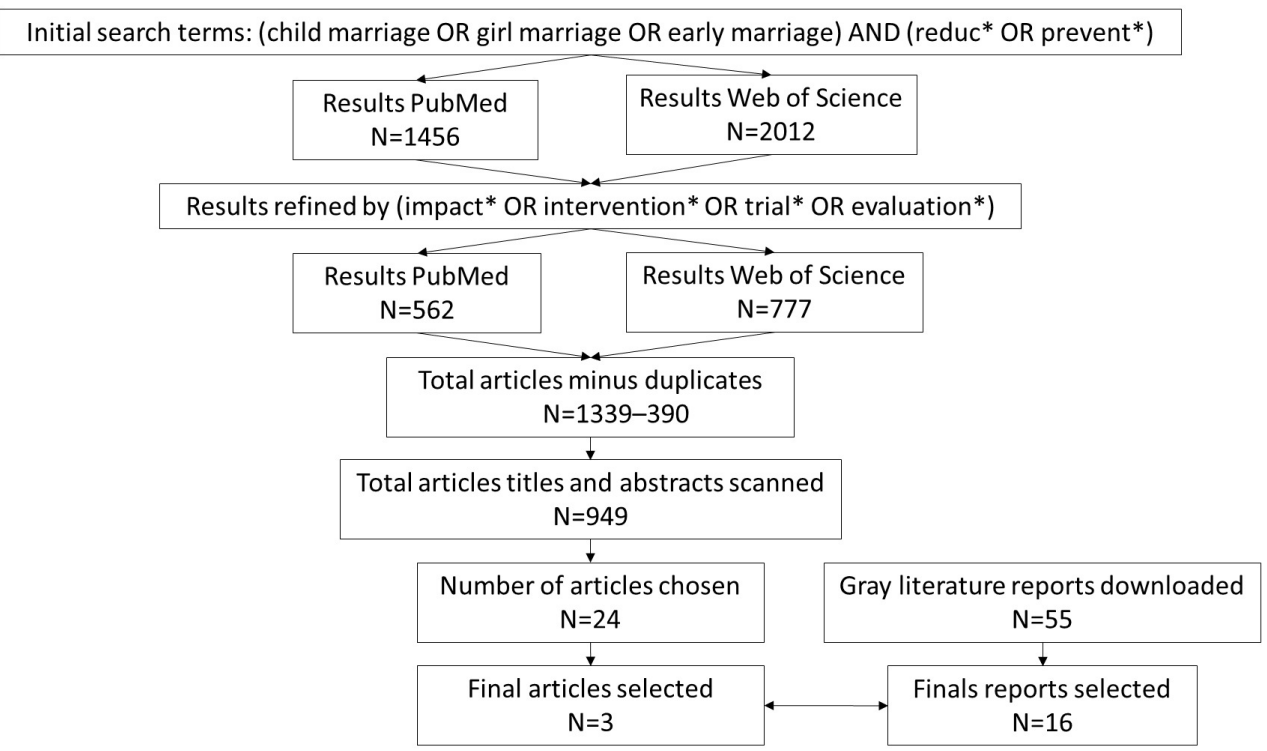

Figure 3. Literature search strategy for interventions on reducing child marriage.

opportunities.

Discussed below are the specific CM and the education interventions used in the modelling. The CM interventions used in the modelling included only life skills and conditional economic incentives. We considered modelling the interventions for community mobilisation ${ }^{24}$ as suggested by Malhotra et al., ${ }^{13}$ however, that indicated a low level of effectiveness, and accordingly was not included in the modelling.

\section{SPECIFIC CHILD MARRIAGE INTERVENTIONS}

The 'Life Skills' programs were represented by the Maharashtra program ${ }^{25,26}$ and the Youth Information Centres program $^{27}$ in Bihar and Uttar Pradesh. Based on these two programs, we adopted an effectiveness rate of $40 \%$. A $70 \%$ reduction in the marriage rate was achieved by the Maha- rashtra Life Skills program with an odds ratio of $4.0,{ }^{26}$ although the likelihood of selection bias in these comparisons and other unobserved variables is acknowledged. Exposure to the Youth Information Centres program ${ }^{27}$ reduced $\mathrm{CM}$ compared with the control group by $56 \%$ (Adj. OR 2.25, CI 1.28-3.94).

For the cost of the life skills program, we used the average of the highly effective but relatively expensive Egyptian Ishraq program of $\$ 31.50$ per girl, and the much cheaper but less effective life skills component of the Indian Deepshika program, ${ }^{4}$ about $\$ 4-6.50$ per girl, which resulted in an average of $\$ 21.50$ per girl.

For the conditional economic incentive interventions, we used the costs and effectiveness of the Kanyashree Prakalpa program, ${ }^{28}$ the only one evaluated in India, at a cost of $\$ 11.55$ per girl and a effectiveness of $32.9 \%$. 
Table 1. Results of literature search, interventions to delay marriage and reduce child marriage rates

\begin{tabular}{|c|c|c|c|c|c|}
\hline $\begin{array}{l}\text { Study; program; } \\
\text { country }\end{array}$ & Targeting & $\begin{array}{l}\text { Main intervention } \\
\text { components }\end{array}$ & Costs & Method & Impact/Outcomes \\
\hline \multicolumn{6}{|l|}{ India } \\
\hline $\begin{array}{l}\text { Pande et al. } \\
\text { (2006), } 25 \text { Pande et } \\
\text { al. (n.d.); } 26 \text { Life } \\
\text { skills course, rural; } \\
\text { Maharashtra, India }\end{array}$ & $\begin{array}{l}\text { Girls aged 12-18 } \\
\text { not in school or } \\
\text { working }\end{array}$ & $\begin{array}{l}\text { 1-year life skills } \\
\text { program as one- } \\
\text { hour sessions each } \\
\text { weekday evening }\end{array}$ & & $\begin{array}{l}\text { Logistic regression } \\
\text { analysis of data } \\
\text { collected from } \\
\text { program \& control } \\
\text { (randomly } \\
\text { selected) villages }\end{array}$ & $\begin{array}{l}\text { Steady decrease in proportion of marriage in girls } 11-17 \text { yrs between } \\
1997 \& 2001 \text { in intervention. No significant change in control. Randomly } \\
\text { selected control } 4 \text { times more likely married before } 18 \text { than those on full } \\
\text { program (pre-18 marriage rate only } 9 \% \text { ). }\end{array}$ \\
\hline $\begin{array}{l}\text { Jejeebhoy et al. } \\
(2009) ; 29 \text { Better } \\
\text { Life Options } \\
\text { programme, group- } \\
\text { based } \\
\text { empowerment } \\
\text { program by } \\
\text { CEDPA; Uttar } \\
\text { Pradesh, India }\end{array}$ & $\begin{array}{l}\text { Unmarried } \\
\text { adolescent girls } \\
\text { 13-17 over a } \\
\text { 6-month period }\end{array}$ & $\begin{array}{l}\text { Life skills } \\
\text { Community } \\
\text { mobilisation }\end{array}$ & & $\begin{array}{l}\text { Quasi- } \\
\text { experimental } \\
\text { evaluating } \\
\text { effectiveness. } \\
\text { Baseline surveys of } \\
\text { all 13-17 yrs old } \\
\text { unmarried girls in } \\
\text { intervention \& } \\
\text { matched control } \\
\text { site pre- } \\
\text { intervention (1038 } \\
\text { girls). Panel survey } \\
\text { 9-15 months later. }\end{array}$ & $\begin{array}{l}\text { Percentage of girls preferring to delay marriage beyond adolescence } \\
\text { increased from } 48-55 \% \text { to } 62-75 \% \text { at endline. }\end{array}$ \\
\hline $\begin{array}{l}\text { Mehra et al. } \\
(2018) ; 27 \mathrm{EU} \\
\text { funded Youth } \\
\text { Information } \\
\text { Centres; Uttar } \\
\text { Pradesh and Bihar, } \\
\text { India }\end{array}$ & $\begin{array}{l}\text { Young girls and } \\
\text { boys } 10-14,15-19 \text {, } \\
20-24\end{array}$ & $\begin{array}{l}\text { Life skill-based } \\
\text { educational } \\
\text { sessions, focusing } \\
\text { on SRH, early } \\
\text { marriage and early } \\
\text { pregnancy }\end{array}$ & & $\begin{array}{l}\text { Cross-sectional } \\
\text { (post-test study) } \\
\text { with a mixed } \\
\text { method approach. } \\
\text { Multi-stage } \\
\text { sampling adopted } \\
\text { for selection of a } \\
\text { sample of } 10-\text { and } \\
\text { 24-year olds. }\end{array}$ & $\begin{array}{l}\text { Intervention strategy showed a significant decrease in number of CMs } \\
\text { (Adjusted Odd Ratios (Adj) } 2 \cdot 25, \mathrm{Cl} 1 \cdot 28-3 \cdot 94 \text { ), of early pregnancies (Adj } \\
3 \cdot 00, \mathrm{Cl} 1 \cdot 06-8 \cdot 43 \text { ) and increase in school retentions (Adj } 2 \cdot 96, \mathrm{Cl} \\
2 \cdot 02-4 \cdot 34 \text { ). }\end{array}$ \\
\hline $\begin{array}{l}\text { CEDPA (2001);30 } \\
\text { BLP - Better Life } \\
\text { Options Program, } \\
\text { peri-urban slums; } \\
\text { Delhi, rural } \\
\text { Madhya Pradesh } \\
\text { and rural Gujrat, } \\
\text { India }\end{array}$ & Adolescent girls & $\begin{array}{l}\text { Life skills } \\
\text { educational } \\
\text { program }\end{array}$ & & $\begin{array}{l}\text { Cross-sectional } \\
\text { impact study }\end{array}$ & $\begin{array}{l}37 \% \text { of BLP girls married after age } 18 \text { compared to } 26 \% \text { in control group. } \\
\text { Control group girls } 35 \% \text { more likely to marry before age } 18 \text { compared to } \\
\text { BLP girls. Quality of valuation unlikely to meet Kalamar et al. }{ }^{22} \\
\text { standards. }\end{array}$ \\
\hline $\begin{array}{l}\text { Pathfinder } \\
\text { International }\end{array}$ & $\begin{array}{l}\text { Young couples and } \\
\text { adolescents }\end{array}$ & $\begin{array}{l}\text { Tackling social } \\
\text { norms pressuring }\end{array}$ & & $\begin{array}{l}960 \text { villages with } \\
10 \text { million people }\end{array}$ & $\begin{array}{l}\text { Young women who took part in the program got married } 2.6 \text { years later } \\
\text { than those who did not and had first babies } 1.5 \text { years later. }\end{array}$ \\
\hline
\end{tabular}




\begin{tabular}{|c|c|c|c|c|c|}
\hline $\begin{array}{l}\text { Study; program; } \\
\text { country }\end{array}$ & Targeting & $\begin{array}{l}\text { Main intervention } \\
\text { components }\end{array}$ & Costs & Method & Impact/Outcomes \\
\hline $\begin{array}{l}\text { (2013); } 31 \\
\text { PRACHAR - } \\
\text { Promoting Change } \\
\text { in Reproductive } \\
\text { Behavior; Bihar, } \\
\text { India }\end{array}$ & & $\begin{array}{l}\text { young people to } \\
\text { marry and have } \\
\text { children early }\end{array}$ & & & \\
\hline $\begin{array}{l}\text { Daniel and Nanda } \\
\text { (2012); } 32 \\
\text { PRACHAR - } \\
\text { Promoting Change } \\
\text { in Reproductive } \\
\text { Behavior; Bihar, } \\
\text { India }\end{array}$ & $\begin{array}{l}\text { Young couples and } \\
\text { adolescents }\end{array}$ & $\begin{array}{l}\text { Tackling social } \\
\text { norms pressuring } \\
\text { young people to } \\
\text { marry and have } \\
\text { children early }\end{array}$ & & $\begin{array}{l}\text { Interviews with } \\
\text { random sample of } \\
307 \text { females and } \\
306 \text { males of } \\
\text { participants and } \\
306 \text { females and } \\
306 \text { males of } \\
\text { comparable ages } \\
\text { non-participants }\end{array}$ & $\begin{array}{l}\text { Among intervention group, median age at marriage for females was } 2 \cdot 6 \\
\text { years higher ( } 22 \cdot 0 \text { vs. } 19 \cdot 4 \text { ) and for males was } 2 \cdot 8 \text { years higher ( } 24 \mathrm{vs} \\
21 \cdot 3) \text { than in the comparison group. Taking schooling and caste } \\
\text { differences into account, the adjusted relative risk of marriage among } \\
\text { females was } 44 \% \text { lower and among males } 26 \% \text { lower for those exposed } \\
\text { to the intervention than among their comparison counterparts. }\end{array}$ \\
\hline $\begin{array}{l}\text { Raj et al. (2017);33 } \\
\text { RISHTA - Regional } \\
\text { Initiative } \\
\text { Supporting Healthy } \\
\text { Adolescents; } \\
\text { Jharkhand, India }\end{array}$ & Boys and girls & $\begin{array}{l}\text { SRH education and } \\
\text { youth } \\
\text { empowerment }\end{array}$ & & $\begin{array}{l}\text { In-depth quality } \\
\text { interviews with } \\
\text { girls aged 13-24 }\end{array}$ & $\begin{array}{l}\text { Changed social norms with later marriage being more acceptable and } \\
\text { improved gender equity. }\end{array}$ \\
\hline $\begin{array}{l}\text { Nanda et al. (2014 } \\
\text { ); }{ }^{34} \text { ABAD - Apni } \\
\text { Beti Apna Dhan } \\
\text { (Our Daughter, Our } \\
\text { Wealth); Haryana, } \\
\text { India }\end{array}$ & $\begin{array}{l}\text { Poor households } \\
\text { and disadvantaged } \\
\text { caste groups }\end{array}$ & $\begin{array}{l}\text { Cash disbursement } \\
\text { for registering } \\
\text { birth of girl; and on } \\
\text { enrolment at } \\
\text { school and saving } \\
\text { bond for daughter } \\
\text { redeemable if girl } \\
\text { unmarried at } 18\end{array}$ & $\begin{array}{l}\text { Savings bond Rs } \\
2500 \text { redeemable } \\
\text { at maturity of Rs } \\
25,000\end{array}$ & $\begin{array}{l}\text { Data from } \\
\text { beneficiaries and } \\
\text { comparable non- } \\
\text { beneficiaries }\end{array}$ & $\begin{array}{l}\text { Study found program did not affect probability of being ever-married or } \\
\text { probability of CM at 18. but ICRW did find that beneficiaries were more } \\
\text { likely to get married exactly at age } 18 \text {. Positive effect on educational } \\
\text { attainment. }\end{array}$ \\
\hline $\begin{array}{l}\text { Nanda et al. } \\
\text { (2016); }{ }^{35} \text { ABAD - } \\
\text { Apni Beti Apna } \\
\text { Dhan (Our } \\
\text { Daughter, Our } \\
\text { Wealth); Haryana, } \\
\text { India }\end{array}$ & $\begin{array}{l}\text { Poor households } \\
\text { and disadvantaged } \\
\text { caste groups }\end{array}$ & $\begin{array}{l}\text { Cash disbursement } \\
\text { for registering } \\
\text { birth of girl; and on } \\
\text { enrolment at } \\
\text { school and saving } \\
\text { bond for daughter } \\
\text { redeemable if girl } \\
\text { unmarried at } 18\end{array}$ & $\begin{array}{l}\text { Savings bond Rs } \\
2500 \text { redeemable } \\
\text { at maturity of Rs } \\
25,000\end{array}$ & $\begin{array}{l}\text { Quasi } \\
\text { experimental, } \\
\text { mixed-methods } \\
\text { design with data } \\
\text { collected from } \\
\text { beneficiaries } \\
\text { (treatment group) } \\
\text { and eligible non- } \\
\text { beneficiaries } \\
\text { (control group), } 2 \\
\text { surveys }\end{array}$ & $\begin{array}{l}\text { Impact evaluation found beneficiary girls were significantly more likely } \\
\text { to complete } 8 \text { th grade than eligible non-beneficiary girls, but no impact } \\
\text { on educational attainment at higher levels. More than } 80 \% \text { of the study } \\
\text { population (including both beneficiaries and non-beneficiaries) had not } \\
\text { married before age } 18 \text { (at the time of the second survey), suggesting a } \\
\text { general societal shift in the age of marriage in Haryana. Of the girls who } \\
\text { were married, no significant difference between beneficiary and non- } \\
\text { beneficiary girls on probability of marriage before } 18 \text { years. }\end{array}$ \\
\hline
\end{tabular}




\begin{tabular}{|c|c|c|c|c|c|}
\hline $\begin{array}{l}\text { Study; program; } \\
\text { country }\end{array}$ & Targeting & $\begin{array}{l}\text { Main intervention } \\
\text { components }\end{array}$ & Costs & Method & Impact/Outcomes \\
\hline $\begin{array}{l}\text { Sen \& Dutta } \\
(2018) ; 28 \\
\text { Kanyashree } \\
\text { Prakalpa (KP); } \\
\text { West Bengal, India }\end{array}$ & $\begin{array}{l}\text { Girls aged } 13-18 \\
\text { years }\end{array}$ & $\begin{array}{l}\text { Conditional cash } \\
\text { transfers }\end{array}$ & $\begin{array}{l}\text { For unmarried girls } \\
\text { aged } 13-18 \\
\text { enrolled in an } \\
\text { educational } \\
\text { institution (KP1) } \\
\text { annual grant Rs } 750 \\
\text { and a onetime } \\
\text { grant of Rs } 25,000 \\
\text { on reaching age } 18 \text {, } \\
\text { providing both } \\
\text { unmarried and at } \\
\text { educ. inst. (KP2) }\end{array}$ & $\begin{array}{l}\text { Independent } \\
\text { primary survey of } \\
1,050 \text { households } \\
\text { from six blocks in } \\
\text { three districts of } \\
\text { West Bengal }\end{array}$ & $\begin{array}{l}\text { Preliminary results: Dropout rate reduced by } 20.6 \% \text { points; marriage } \\
\text { rate by } 12.3 \% \text { points or a } 32 \cdot 9 \% \text { reduction. }\end{array}$ \\
\hline $\begin{array}{l}\text { Sambodhi } \\
\text { (2014); } 36 \\
\text { Maharashtra, India }\end{array}$ & $\begin{array}{l}\text { Adolescent girls } \\
12-18\end{array}$ & $\begin{array}{l}\text { Life Skills Project } \\
\text {-Deepshika, } \\
\text { empowering girls } \\
\text { State Gender } \\
\text { resource centre - } \\
\text { network of support }\end{array}$ & $\begin{array}{l}\text { Per participant cost } \\
\text { ranged from } \\
\text { INR267 to INR455 } \\
\text { (US\$4-6.50) }\end{array}$ & $\begin{array}{l}\text { Large program } \\
\text { reaching } 64,360 \\
\text { girls. Results based } \\
\text { on interviews with } \\
\text { girls, parents, } \\
\text { service providers } \\
\text { and frontline } \\
\text { workers - sample } \\
\text { for endline covered } \\
583 \text { girls in project } \\
\text { and } 324 \text { in } \\
\text { comparison areas. }\end{array}$ & $\begin{array}{l}\text { Impact on gender knowledge and attitudes strongly evident within } \\
\text { communities - several young women elected into local self-governance } \\
\text { bodies, some heading their gram panchayats, now active at village level } \\
\text { and active part family level decision making. Changes within families } \\
\text { evident, especially attitudes towards girls. However reduction in number } \\
\text { of CM (280) small compared with large program size. }\end{array}$ \\
\hline \multicolumn{6}{|l|}{ Other countries } \\
\hline $\begin{array}{l}\text { Zibani }(2012)^{37} \text { in } \\
\text { Sewall-Menon \& } \\
\text { Bruce (2012);3 } \\
\text { Ishraq (Sunrise) } \\
\text { Program; Upper } \\
\text { Egypt }\end{array}$ & $\begin{array}{l}\text { Disadvantaged } \\
\text { out-of-school, rural } \\
\text { adolescent girls } \\
\text { aged } 12-15\end{array}$ & $\begin{array}{l}\text { Life skills } \\
\text { Community } \\
\text { mobilisation }\end{array}$ & $\begin{array}{l}\text { Life skills costs per } \\
\text { girl } \$ 17.99 \mathrm{Admin} \text {. } \\
\text { costs pro rata } \\
\$ 13.50 \text { Total costs } \\
\$ 31.50\end{array}$ & $\begin{array}{l}\text { Monitored \& } \\
\text { evaluated with } \\
\text { surveys of } \\
\text { intervention } \\
\text { villages \& control } \\
\text { villages with no } \\
\text { intervention }\end{array}$ & $\begin{array}{l}\text { No results at time of study, but indicators developed \& program scaled- } \\
\text { up. }\end{array}$ \\
\hline $\begin{array}{l}\text { Brady et al. } \\
\text { (2007); } 39 \text { Ishraq } \\
\text { (Sunrise) Program; } \\
\text { Upper Egypt }\end{array}$ & $\begin{array}{l}\text { Disadvantaged } \\
\text { out-of-school, rural } \\
\text { adolescent girls in } \\
4 \text { rural villages - } 2 \\
\text { in Ishraq, } 2 \text { in } \\
\text { control group }\end{array}$ & $\begin{array}{l}\text { Social norms Safe } \\
\text { spaces }\end{array}$ & & $\begin{array}{l}\text { Longitudinal } \\
\text { surveys of girls } \\
\text { aged } 13-15\end{array}$ & $\begin{array}{l}\text { Marriage rates at endline among non-participants in program villages } \\
\text { higher than in control villages ( } 22 \% \text { vs } 16 \%) \text {. Rate of } 13-29 \text { months } \\
\text { participating } 12 \% \text {, with full-time participants } 5 \% \text {. }\end{array}$ \\
\hline $\begin{array}{l}\text { Erulkar \& } \\
\text { Muthengi }\end{array}$ & $\begin{array}{l}\text { Married \& } \\
\text { unmarried girls }\end{array}$ & $\begin{array}{l}\text { Community } \\
\text { mobilisation Girls' }\end{array}$ & $\begin{array}{l}\text { Cost of materials, } \\
\text { e.g. pencils, }\end{array}$ & $\begin{array}{l}\text { Baseline } \& \text { endline } \\
\text { ( } 2 \text { years later) of } 2\end{array}$ & $\begin{array}{l}\text { Improvements in girls' school enrolment, age at marriage, etc. } \\
\text { Particularly for girls } 10-14 \text { in program rather than in control area, more }\end{array}$ \\
\hline
\end{tabular}




\begin{tabular}{|c|c|c|c|c|c|}
\hline $\begin{array}{l}\text { Study; program; } \\
\text { country }\end{array}$ & Targeting & $\begin{array}{l}\text { Main intervention } \\
\text { components }\end{array}$ & Costs & Method & Impact/Outcomes \\
\hline $\begin{array}{l}\text { (2009); } 40 \text { Berhane } \\
\text { Hewan; Ethiopia }\end{array}$ & aged 10-19. & $\begin{array}{l}\text { education } \\
\text { incentives } \\
\text { Conditional } \\
\text { economic } \\
\text { incentives, e.g. } \\
\text { chickens or goat }\end{array}$ & $\begin{array}{l}\text { notebooks \$US4 } \\
\text { Provision of goat/ } \\
\text { pregnant ewe } \\
\text { (\$US20) if girl } \\
\text { unmarried at } 18\end{array}$ & $\begin{array}{l}\text { villages with similar } \\
\text { SES profiles }-1 \\
\text { program \& other } \\
\text { control; Chi-square } \\
\text { tests, proportional } \\
\text { hazards models \& } \\
\text { logistic regressions }\end{array}$ & $\begin{array}{l}\text { likely to be in school (odds ratio, } 3 \cdot 0) \text { \& less likely to have ever been } \\
\text { married (0.1). But, girls aged } 15-19 \text { in intervention, elevated likelihood } \\
\text { of having been married by endline (2.4). }\end{array}$ \\
\hline $\begin{array}{l}\text { Erulkar (2014); } 41 \\
\text { Berhane Hewan; } \\
\text { sub-Saharan Africa }\end{array}$ & Girls aged $10-14$ & $\begin{array}{l}\text { Community } \\
\text { mobilisation Girls' } \\
\text { education } \\
\text { incentives } \\
\text { Conditional } \\
\text { economic } \\
\text { incentives, e.g. } \\
\text { chickens or goat }\end{array}$ & $\begin{array}{l}\text { Full model costs in } \\
\text { Ethiopia } \$ 44 \text { per } \\
\text { girl; in Tanzania } \\
\$ 117 \text { per girl }\end{array}$ & $\begin{array}{l}\text { Quasi- } \\
\text { experimental } \\
\text { research design, } \\
\text { with population- } \\
\text { based surveys } \\
\text { before \& after } \\
\text { implementation, in } \\
\text { intervention \& } \\
\text { control sites }\end{array}$ & $\begin{array}{l}\text { Ethiopia: Education support, } 94 \% \text { less likely to get married at endline. } 2 \\
\text { chickens for every year unmarried, girls } 15-17 \text { yrs were } 50 \% \text { likely. Full } \\
\text { model, girls aged } 15-17 \text { yrs, were two-thirds less likely to be married. } \\
\text { Tanzania: With goats, girls 5-17 yrs, two thirds less likely to be married. } \\
\text { Full model positive effect among both groups of girls. }\end{array}$ \\
\hline $\begin{array}{l}\text { Erulkar et al. } \\
\text { (2017); }{ }^{4} \text { Berhane } \\
\text { Hewan; Burkina } \\
\text { Faso, Ethiopia \& } \\
\text { Tanzania }\end{array}$ & $\begin{array}{l}\text { Cross section of } \\
\text { men, women } \\
\text { adolescent males \& } \\
\text { females }\end{array}$ & $\begin{array}{l}\text { Community } \\
\text { mobilisation Girls' } \\
\text { education } \\
\text { incentives } \\
\text { Conditional } \\
\text { economic } \\
\text { incentives }\end{array}$ & $\begin{array}{l}\text { Conditional cash } \\
\text { transfer cost in: } \\
\text { Ethiopia } \$ 32 \\
\text { Tanzania } \$ 107 \\
\text { Average } \$ 69 \cdot 50\end{array}$ & $\begin{array}{l}\text { Population-based } \\
\text { base line \& endline } \\
\text { surveys of girls } \\
\text { aged } 12-17 \& \\
\text { parents of girls }\end{array}$ & $\begin{array}{l}\text { Ethiopia: among girls aged } 15-17 \text {, with conditional asset transfer half the } \\
\text { risk of being married at endline compared to baseline } R R=0.57 \\
\text { Tanzania: } R R=0.52\end{array}$ \\
\hline $\begin{array}{l}\text { Catino et al. } \\
(2012)^{42} \text { in Sewall- } \\
\text { Menon \& Bruce } \\
\text { (2012);38 Abriendo } \\
\text { Oportunidades; } \\
\text { Guatemala }\end{array}$ & $\begin{array}{l}\text { Disadvantaged } \\
\text { rural girls aged } \\
8-24\end{array}$ & $\begin{array}{l}\text { Life skills Safe } \\
\text { spaces for girls } \\
\text { Building social } \\
\text { networks }\end{array}$ & & $\begin{array}{l}\text { Project monitoring } \\
\text { with feedback } \\
\text { throughout the } \\
\text { project cycle to } \\
\text { adjust project } \\
\text { strategies, \& } \\
\text { evaluation to } \\
\text { assess project } \\
\text { effectiveness as } \\
\text { measured against } \\
\text { outcome indicators }\end{array}$ & $\begin{array}{l}\text { Core outcome indicators for beneficiaries during pilot: } \\
\text { - Continuation of education } \\
\text { - Delayed age at marriage \& first birth } \\
\text { - Retention of health \& economic assets after program } \\
\text { - Leadership \& teaming capacity }\end{array}$ \\
\hline
\end{tabular}


Table 2. Costs and outcomes model, reductions in child marriage rates for 15-17 year-olds, compared with base*, percentage points

\begin{tabular}{|l|c|c|}
\hline Year & CM interventions only & All interventions \\
\hline 2030 & $-0.8 \%$ & $-6.1 \%$ \\
\hline 2050 & $-1.2 \%$ & $-7.5 \%$ \\
\hline
\end{tabular}

Note: *Base excludes trend decline.

\section{EDUCATION INTERVENTIONS}

Education interventions, which also reduced CM rates, were derived from a meta-analysis. ${ }^{20}$ It measured the impact of education interventions to reduce secondary school dropout rates in terms of standard deviations. Only those showing an effect size in excess of 0.1 standard deviations for either learning improvement or dropout reduction were selected. The evidence suggested those which had a significant impact on $\mathrm{CM}^{20,43}$ were (with their standard deviations in brackets):

1. Increase provision of school in rural areas to give girls greater access to schools (S.D. $0.38(\rho=0.27))$.

2. Improve educational infrastructure, e.g. provision of girls' latrines $(\mathrm{SD}=0.12(\rho=0.0))$.

3. Pedagogical changes $(\mathrm{SD}=0.13(\rho=0.004))$.

4. Private public partnerships $(\mathrm{SD}=0.15(\rho=0.136))$.

The costs of the education interventions derived from Wils et al. ${ }^{20}$ are expressed as percentages of the base cost of Indian education programs. The costs are respectively $10 \%$, $5 \%$ and $10 \%$ for points 1,2 , and 3 above, and a negligible cost for point 4 above.

\section{MODELLING FRAMEWORK}

In line with the theory of change, ${ }^{16,17}$ we developed a simulation/modelling study, which aimed to synthesize the available evidence on CM in India. The basic methodological approach followed our previous paper. ${ }^{21}$

Two Microsoft Excel models were used to undertake the cost-benefit analysis: a cost and outcomes model which generated education costs and other education outcomes; and a benefits model which forecast economic benefits from employment, GDP levels and productivity gains. The modelling compared two scenarios, a continuation of existing conditions described as 'base scenario', and an 'intervention scenario' which included the interventions discussed above. For the 'base scenario', the cost and outcomes model projected base education costs, as well as CM prevalence and education enrolments. The intervention scenario estimated the impact of the interventions on this base scenario from 2020. The benefit-cost ratios are calculated on the basis that the annual cost of the interventions increases progressively to 2030, thereafter remaining constant to 2050. The benefits are modelled to include productivity and employment gains until retirement for each age cohort.

To estimate the CM prevalence for 2020, we projected the rate from the 2016 National Family and Health Survey. To estimate the marriage rate for those aged 15-17 in 2020, we used the declining trend in the estimated single-year marriage rates from the Survey to project the rate for 2020. We estimated that the rate would have declined to $16.4 \%$ by 2020. We used this as the starting CM rate for the benefitcost analysis.

For the intervention scenario, the models were run with the addition of the interventions discussed above. With the cost model, new estimates of education costs, student enrolments and child marriage prevalence were calculated, and the benefits model generated new estimates of productivity gains, employment levels and GDP, based on the improved education outcomes. The additional economic gains from the employment and productivity effects, arising from the interventions, were compared with the costs of the interventions, to enable the benefit-cost ratios to be calculated. ${ }^{18,20,21,44}$ The sensitivity of the benefit-cost ratios to different intervention cost and effectiveness assumptions was tested by varying each by $+/-10 \%$.

These models made extensive use of international data sources: UNICEF, ${ }^{45}$ UNESCO Institute for Statistics (UIS), ILO, and the World Bank Development Indicators and EdStats database. Indian data came from the National Sample Survey (NSS), the Annual Status of Education Report and the District Information System for Education.

\section{RESULTS}

\section{REDUCTION IN CHILD MARRIAGE RATES}

The application of all interventions reduced the marriage rate for those aged $15-17$ from the base of $16.4 \%$ in 2020 by 7.5 percentage points in 2050 (excluding any further trend decline), to $8.9 \%$ (Table 2). Much of the impact was estimated to be achieved by 2030 with a reduction of 6.1 percentage points. The effect of the child marriage interventions, however, was modest with reductions of only 0.8 and 1.2 percentage points by 2030 and 2050 (Table 2).

This shows that the education inventions have a greater effect on the CM rate than the specific marriage interventions. However, we estimate that the net present value of costs to 2050 of the education interventions was six times larger, $\$ 243$ billion, compared with $\$ 40$ billion for the specific marriage interventions.

Regrettably, the severe effect of COVID appears likely to interrupt the downward trend in poverty and CM in India. ${ }^{46,47}$ We estimate that the effect of COVID 19 in 2020-21 will be to lift the estimated number of CMs by 179,000 , an increase of almost $3 \%$. This is based on the de- 
Table 3. Benefits model, education and productivity gains from specific child marriage and educational interventions for girls, percentage points (i) and \% (ii)

\begin{tabular}{|c|c|}
\hline & Total \\
\hline \multicolumn{2}{|c|}{ (i) Change in educational outcomes relative to the base case in 2030} \\
\hline \multicolumn{2}{|c|}{ Share of 20-24 year olds girls who have completed year 12 (percentage points increase) } \\
\hline Child marriage (CM) interventions & 2.0 \\
\hline Education interventions (CM only) & 11.6 \\
\hline Total & 13.1 \\
\hline \multicolumn{2}{|c|}{ (ii) Productivity effect for $20-24$ year old girls (change by $2030, \%$ ) } \\
\hline \multicolumn{2}{|l|}{ Child marriage } \\
\hline Additional years of schooling effect & 0.2 \\
\hline Change in employment level and type & 1.6 \\
\hline Total & 1.8 \\
\hline \multicolumn{2}{|l|}{ Education interventions (EI) } \\
\hline Additional years of schooling effect & 5.0 \\
\hline Change in employment level and type & 9.3 \\
\hline Total & 14.8 \\
\hline \multicolumn{2}{|l|}{ Total CM and educational interventions } \\
\hline Additional years of schooling effect & 5.4 \\
\hline Change in employment level and type & 10.5 \\
\hline Total & 16.4 \\
\hline
\end{tabular}

cline of 9\% in per capita income for India in 2020-21 compared with a year earlier. ${ }^{48}$ Paul $^{49}$ has shown that CM increases by $0.3 \%$ for $1 \%$ increase in poverty, meaning that the marriage rate would increase by 2.7 percentage points, representing an additional 155,000 CMs. In addition, the number of 15-17 year old girls who will now be poor (less than $\$ 2$ per day), and a have a higher propensity to marry, is estimated to have increased from 6 million to 13.4 million. Based on our modelling, this is estimated to add a further 22,000 to the number married.

At this early stage, it is difficult to project the impact of COVID on the longer-term decline in CM in India and we have not attempted to do so. However, it would appear that a greater investment than modelled here will be required to achieve the level projected in this study.

\section{BETTER SCHOOLING OUTCOMES AND INCREASED PRODUCTIVITY}

Table 3 presents schooling and productivity effects for the education and specific CM interventions. The interventions increase the share of girls completing secondary education by 13.1 percentage points to 2030 . The education interventions had the larger effect, shifting completions by 11.6 percentage points compared with 2.0 for the marriage interventions.

Improved schooling outcomes were assumed to increase productivity. It is assumed that each additional year of schooling provides an economic return by way of increased income, and secondary school completions increase the number of girls employed and the proportion engaged in formal employment. ${ }^{18}$ The immediate economic effect of increased schooling is negative because it withdraws girls from the workforce. This is later offset, as a higher proportion of the cohort enters the workforce in more productive roles. Table 3 shows the productivity changes, for the two productivity effects and the two sets of interventions to 2030. Overall, the productivity improvement for both sets of interventions is $16.4 \%$, of which $14.8 \%$ is a result of the education interventions and $1.8 \%$ for the CM interventions.

The change in employment type (increased formal employment) had a larger effect on productivity, than did the additional years of schooling. The change in employment level and type had a productivity effect of $10.5 \%$, compared with $5.4 \%$ of the additional years of schooling effect.

\section{BENEFIT-COST RATIOS}

Our study calculated the benefit-cost ratios based on total employment benefits as a ratio of the total costs of the relevant education interventions and the specific CM ones discussed above. The modelling assumed that coverage of the interventions is progressively increased to reach an $11.3 \%$ target level by $2030 . .^{20}$ Both costs and benefits are discounted at $3 \%$.

Table 4 shows relevant benefit-cost ratios for four education interventions and two specific CM interventions. The ratios for all interventions is 16.8 , meaning that there are almost $\$ 17$ in economic benefits for every dollar invested. This is very high. It would be lower if the benefits were to be evaluated over a more limited period. Including the benefits to retirement age reflects the fact that the benefits of additional education are transformational and last for their working lifetime. The benefit-cost ratio is 13.1 for the ed- 
Table 4. Benefit-cost ratios for the impact of education and child marriage interventions benefits

\begin{tabular}{|l|c|c|c|}
\hline Time period & \multicolumn{3}{|c|}{ Benefit-cost ratio $^{*}$} \\
\hline Benefits to retirement age & All interventions & Marriage only & Education only \\
\hline
\end{tabular}

Note: "discount rate $3 \%$.

ucation interventions and 21.0 for the CM interventions. While productivity and schooling gains of the education interventions are larger, so is their cost.

The benefit-cost ratio remains high, 14.9, even when the intervention costs are increased by $10 \%$ and their effectiveness reduced by $10 \%$. It increases to 18.9 if more favourable assumptions are adopted, a $10 \%$ reduction in intervention costs and an increase of $10 \%$ in effectiveness.

To explore the effect of regional differences, modelling was conducted for two states with contrasting economic circumstances, the relatively well-off Tamil Nadu and relatively poor Madhya Pradesh, illustrated in Figure 1. While Tamil Nadu had a secondary completion rate for girls of $79.4 \%$ in 2018 , it was only $46.3 \%$ in Madhya Pradesh. However, by 2050, it was projected to increase by 32.3 percentage points for Madhya Pradesh to $79.1 \%$, but only 11.1 percentage points to $90.6 \%$ for Tamil Nadu. While the benefit-cost ratios are the outcome of the interaction of many factors, there is a marked difference in the two ratios, 14.8 for Madhya Pradesh and 9.0 for Tamil Nadu, indicating the benefit of this relative outperformance by the poorer state catching up with an already well-performing betterendowed state.

\section{DISCUSSION}

As discussed, CM is the outcome of the complex interactions of many factors which include poverty, level of education, and social and cultural attitudes. While CM in India has on average declined sharply over the intercensal decade to 2016, progress has been very uneven between regions, rural and urban areas, income groups and education levels. This study indicates that ongoing interventions in education, and social and cultural attitudes are still a highly valuable investment in continuing this reduction in CM with an overall benefit-cost ratio of 16.8 , meaning that there are almost \$17 in economic benefits for every dollar invested.

In modelling the two sets of interventions separately, we show that the direct $\mathrm{CM}$ interventions deliver a higher benefit-cost ratio (21.0) than the education interventions (13.1). This is partly due to the relatively high costs of the education interventions compared with the CM ones. The cost of the education interventions range from $\$ 3,200$ to $\$ 5,900$ per girl, compared with the CM interventions which are in the range $\$ 12-\$ 22$ per girl. The education interventions which we modelled are all supply-side interventions to make education more attractive (closer, more girlfriendly schools with better-trained teachers). In contrast, the CM interventions increase demand by providing conditional non-cash incentives to delay marriage and life skills programs to empower girls to remain unmarried and there- fore to stay longer at school.

While these results certainly support the expansion of $\mathrm{CM}$ intervention programs, they should not be undertaken at a cost to the education system, since the two are interdependent. The benefits of the CM interventions arise because they allow girls to stay at school. Ultimately, a quality and accessible education system is fundamental to providing the skills and training necessary to generate very large economic benefits. As Malhotra and Elnakib argue, 'the enhancement of girls' own human capital and opportunities is the most compelling pathway to delaying marriage'. ${ }^{23(p 1)}$ Together, the two sets of interventions act to discourage girls from dropping out of school and continuing in their studies to complete secondary school. They deliver large benefits not only in improved productivity for every year of additional schooling, but also in the opportunity to find higher paid jobs in the formal sector. ${ }^{50-54}$

In communities where girls are systematically excluded from participation in social, economic and political life, CM represents a serious human rights issue for individual girls. Delaying marriage and extending years at school have benefits that go beyond enhanced employment opportunities and higher incomes. There are other benefits, such as reduced fertility and improved health outcomes, not included in this study. ${ }^{55}$ Together with the employment benefits, these benefits are transformational for communities with high levels of poverty. Better-educated women with smaller families are better placed to break the intergenerational cycle of early marriage, limited education and low incomes. 56,57

The context in which these interventions are being evaluated is undoubtedly important. Our analysis for the UNFPA showed that since 1990, trends in countries with high CM prevalence could be placed in three categories of almost equal size, as trending down, stuck after a downward shift or no change/increase. ${ }^{58(p 91-113)}$ The Indian context has been supportive to reducing $\mathrm{CM}$ and therefore is favourable to the effectiveness of our modelled interventions. However, the impact of COVID is to cause a significant retracement of poverty rates, making reductions in $\mathrm{CM}$ more difficult and stimulating the requirement for greater investment to continue the downward trend. Other countries which have demonstrated the effectiveness of these interventions, but which now face rising COVID-related poverty, may also find greater resistance to reductions in $\mathrm{CM}$ using these interventions and require increased investment in expanded programs to reduce CM. ${ }^{59}$

\section{LIMITATIONS}

As with all modelling exercises, the results produced here 
depend on the assumptions made in specifying the relevant variables. Some causes of CM were not modelled. Moreover, the relationships between $\mathrm{CM}$, education and employment outcomes are complex, and the direction of causation is often highly interdependent. It is not possible, given the limited evidence, to capture all these relationships.

In deriving the effectiveness and cost parameters from the CM intervention literature, we acknowledge that we are adopting an experimental approach in which the outcomes with and without the interventions are compared. ${ }^{60}$ While there are weaknesses in such an approach, one strength is that we are able to test the cost effectiveness of interventions based on the results of actual field experiments. ${ }^{60,61}$ A limitation of the approach is that some relevant interventions may not have been formally evaluated and we are unable to include their impact in our modelling. Offsetting that limitation is that those deemed most important tend to be those that have been evaluated.

Accordingly, the modelling attempts to incorporate the most important relationships based on the best understanding from the available evidence. Nonetheless, this analysis relies on a small number of studies, not all of them Indian. Furthermore, the results of these studies are broadly applied to contexts which may be very different from those where the results were produced. Even so, the benefit-cost ratios are very high permitting substantially higher costs or lower effectiveness in the implementation of the modelled interventions, without undermining the very advantageous economic outcomes from investing in reducing CM.

\section{CONCLUSIONS}

Modelling the impacts of education interventions and child marriage interventions on early marriage makes it possible to compare the value of the economic and social gains from reducing child marriage, with the costs of the interventions to do so. This study suggests that interventions that reduce child marriage through increased attendance at school and changing social attitudes to child marriage, are both socially important and economically valuable. While the knowledge of impact and costs remain imperfect, the benefit-cost ratios are robust for different intervention levels. The interventions generate economic and social benefits that are many times their costs, leaving a significant margin for error. While the COVID 19 pandemic has introduced new uncertainties into outcomes modelled in this paper, with the extent of the economic downturn yet to be realised, the pandemic can only have exacerbated the factors driving poor families to marry off their daughters. There is even more reason for the interventions identified in this paper to be implemented.

\section{ACKNOWLEDGEMENTS}

The authors are grateful for the advice and support of Howard Friedman, Venkatesh Srinivasan, Devender Singh and Shobhana Boyle of UNFPA.

\section{FUNDING}

The authors gratefully acknowledge funding support from the UN Populations Fund (UNFPA/IND/2018/003).

\section{AUTHORSHIP CONTRIBUTIONS}

BR, NM and PJS conceptualized this paper and drafted it with contributions from SS, AK and RK. JS provided the data and modeling, and participated in the analysis. MK conducted the formal literature review strategy and did the overall edit. All authors reviewed the findings. All authors agreed with the final version of the paper.

\section{COMPETING INTERESTS}

The authors completed the Unified Competing Interest form at www.icmje.org/coi_disclosure.pdf (available upon request from the corresponding author), and declare no conflicts of interest.

\section{CORRESPONDENCE TO:}

Bruce Rasmussen, Victoria Institute of Strategic Economic Studies, Victoria University, PO Box 14428, Melbourne, Victoria, 8001, Australia.

Bruce.Rasmussen@vu.edu.au

Submitted: November 12, 2020 GMT, Accepted: March 06, 2021 GMT 


\section{REFERENCES}

1. Centre for Child Rights. Centre for Child Rights. Handbook on the Prohibition of Child Marriage Act, 2006. UNICEF and Ministry of Women and Child Development; 2009. Accessed October 11, 2018. http s://www.childlineindia.org.in/pdf/Child-Marriage-ha ndbook.pdf

2. UNFPA. Marrying too young: End child marriage.; 2012. Accessed September 28, 2017. http://www.unfp a.org/sites/default/files/pub-pdf/MarryingTooYoung.p df

3. Sachdev C. UNICEF's good news about child marriage isn't quite as good as it sounds. National Public Radio; 2018. Accessed October 11, 2018. http s://www.npr.org/sections/goatsandsoda/2018/03/14/5 93155781/unicefs-good-news-about-child-marriage-i snt-quite-as-good-as-it-sounds

4. UNICEF. End child marriage: India has the largest number of brides in the world - one-third of the global total. Accessed October 1, 2020. https://www.unicef.o rg/india/what-we-do/end-child-marriage\#: :text=Esti mates\%20suggest\%20that\%20each\%20year,15\%2D1 9\%20are\%20currently\%20married

5. IIPS, Macro International. National family health survey (NFHS-3) 2005-06. International Institute for Population Sciences; 2007. Accessed October 11, 2018. http://rchiips.org/nfhs/NFHS-Also2015-16 3\%2 0Data/VOL-1/India volume I corrected 17oct08.pdf

6. IIPS, ICF India. National family health survey (NFHS-4), 2015-16: India. International Institute for Population Sciences; 2017. Accessed May 6, 2020. http s://dhsprogram.com/pubs/pdf/FR339/FR339.pdf

7. Reserve Bank of India. Table 9: Per capita net state domestic product - state-wise. In: Handbook of statistics on Indian economy 2018-19. Reserve Bank of India; 2019:31-33. Accessed May 6, 2020. https://ww w.rbi.org.in/scripts/PublicationsView.aspx?id=19001

8. Zavier AJF, Basu S, Santhya KG. Factors associated with decline in child marriage in India: Findings from a district-level analysis. Population Council; 2019. Accessed June 3, 2020. https://ajws.org/wp-content/u ploads/2019/08/AJWS-Brief-2 13-8-19.pdf

9. Kumar S. Evidences from large-scale surveys: Trends, differentials and determinants of child marriage in India - National Family Health Survey-4. Econ Political Wkly. 2020;55(6):8. Accessed June 3, 2020. https://www.epw.in/journal/2020/6/national-fa mily-health-survey-4/trends-differentials-and-deter minants-child.html
10. Wodon Q, Male C, Nayihouba A, et al. Economic impacts of child marriage: Global synthesis report. World Bank and International Centre for Research for Women; 2017. Accessed September 28, 2017. http://do cuments.worldbank.org/curated/en/530891498511398 503/pdf/116829-WP-P151842-PUBLIC-EICM-GlobalConference-Edition-June-27.pdf

11. Jha J. Reducing child marriage in India: A model to scale up results. Centre for Policy and Budget Studies and UNICEF; 2016. Accessed May 18, 2021. https://ide as.repec.org/p/ess/wpaper/id10580.html.

\section{UNICEF. Early marriage: A harmful traditional} practice.; 2005. Accessed May 18, 2021. https://www.u nicef.org/gender/files/Early_Marriage_Harmful Tradit ional Practice.pdf.

13. Malhotra A, Warner A, McGonagle A, Lee-Rife S. Solutions to end child marriage: What the evidence shows. International Centre for Research on Women; 2011. Accessed August 3, 2018. https://www.icrw.org/ wp-content/uploads/2016/10/Solutions-to-End-Chil d-Marriage.pdf

14. Sethi NK, Rao SS, Aggarwal OP, Indrayan A, Chuttani CS. Age at marriage, gauna (effective marriage) and first child birth in rural women: Changing pattern in various marriage cohorts by decades. Indian J Community Med.

2011;13(4):166-169. Accessed June 3, 2020. http://rep ository.ias.ac.in/73493/

15. Pandit Govind Ballabh Pant Institute of Studies in Rural Development. Child marriage in India: a study of situation, causes and enforcement of prohibition of Child Marriage Act. Final Report. Planning Commission, Government of India; 2015. Accessed May 11, 2020. https://ideas.repec.org/p/ess/wpaper/id 6900.html\#download

16. Girls not Brides. Vision: A world without child marriage where girls and women enjoy equal status with boys and men and are able to achieve their full potential in all aspects of their lives.; 2014. Accessed May 18, 2021. https://www.girlsnotbrides.org/about-us/.

17. UNICEF. UNFPA-UNICEF Global Programme to End Child Marriage.; 2017. Accessed June 3, 2020. http s://www.unicef.org/protection/unfpa-unicef-global-p rogramme-end-child-marriage

18. Sheehan P, Shi H. Employment and productivity benefits of enhanced educational outcomes: A preliminary modelling approach. J Adolesc Health. 2019;65(1):S44-S51. doi:10.1016/j.jadohealth.2019.0 3.025 
19. Sheehan P, Sweeny K, Rasmussen B, et al. Building the foundations for sustainable development: A case for global investment in the capabilities of adolescents. Lancet. 2017;390(10104):1792-1806. do $\mathrm{i}: 10.1016 / \mathrm{s} 0140-6736(17) 30872-3$

20. Wils B, Sheehan P, Shi H. Better schooling outcomes for adolescents in low- and middle-income countries: projections of cost-effective approaches. $J$ Adolesc Health. 2019;65(1):S25-S33. doi:10.1016/i.jad ohealth.2019.03.024

21. Rasmussen B, Maharaj N, Sheehan P, Friedman HS. Evaluating the employment benefits of education and targeted interventions to reduce child marriage. $J$ Adolesc Health. 2019;65(1):S16-S24. doi:10.1016/j.jad ohealth.2019.03.022

22. Kalamar AM, Lee-Rife S, Hindin MJ. Interventions to prevent child marriage among young people in low- and middle-income countries: A systematic review of the published and gray literature. J Adolesc Health. 2016;59(3 Suppl):516-521. doi:10.1016/i.jado health.2016.06.015

23. Malhotra A, Elnakib S. 20 years of the evidence base on what works to prevent child marriage: a systematic review. J Adolesc Health. 2021;68(5):847-862. doi:10.1016/i.jadohealth.2020.1 $\underline{1.017}$

24. Erulkar A, Medhin G, Weissman MA. The impact and cost of child marriage prevention in three African settings. Population Council; 2017. Accessed August 7, 2018. https://www.popcouncil.org/uploads/pdfs/2017 PGY_ChildMarriageAfrica_brief.pdf

25. Pande R, Kurz K, Walia S, MacQuarrie K, Jain S. Improving the reproductive health of married and unmarried youth in India: Evidence of effectiveness and costs from community based interventions.

International Centre for Research on Women; 2006. Accessed September 28, 2017. https://www.icrw.org/w p-content/uploads/2016/10/Improving-the-Reproduc tive-Health-of-Married-and-Unmarried-Youth-in-Ind ia.pdf

26. Pande R, Kurz K, Walia S, MacQuarrie K, Jain S. Improving the reproductive health of married and unmarried youth in India: Delaying age at marriage in rural Maharashtra, India. International Centre for Research on Women Accessed August 31, 2018. http s://www.icrw.org/files/images/Delaying-Age-at-Marri age-in-Rural-Maharashtra-India.pdf

27. Mehra D, Sarkar A, Sreenath P, Behera J, Mehra S. Effectiveness of a community based intervention to delay early marriage, early pregnancy and improve school retention among adolescents in India. BMC Public Health. 2018;18(1):732-745. doi:10.1186/s1288 9-018-5586-3
28. Sen A, Dutta A. West Bengal's successful Kanyashree Prakalpa programme needs more push from state and beneficiaries. Econ Political Wkly. 2018;53(17). Accessed October 18, 2018. https://ww w.epw.in/engage/article/West-Bengal-Successful-Kan yashree-Prakalpa-Programme-Needs-More-Push-Fro m-State-and-Beneficiaries

29. Acharya R, Kalyanwala S, Jejeebhoy SJ, Nathani V. Broadening girls' horizons: Effects of a life skills education program in rural Uttar Pradesh. Population Council; 2009. Accessed May 18, 2021. https://knowle dgecommons.popcouncil.org/departments_sbsr-pgy/1 $\underline{009 / .}$

30. CEDPA. Adolescent girls in India choose a better future: An impact assessment CEDPA Better Life Options Program. Office of Population, Family Planning Services Division, Centre for Development and Population Activities; 2001. Accessed October 11, 2018. http://genderlinks.org.za/wp-content/uploads/i mported/articles/attachments/13177_file blp_report.p df

31. Pathfinder International. Promoting change in reproductive behavior in Bihar (PRACHAR).; 2013. Accessed October 11, 2018. http://www.pathfinder.or g/projects/prachar/

32. Daniel EE, Nanda R. The effect of reproductive health communication interventions on age at marriage and first birth in rural Bihar, India: A retrospective study. Pathfinder International; 2012. Accessed October 20, 2020. https://www.pathfinder.org/wp-con tent/uploads/2016/11/The-Effect-of-Reproductive-he alth-Communication-Interventions-on-Age-at-Marri age-and-First-Birth-in-Rural-Bihar-India.pdf

33. Raj A, McDougal L, Jackson E. Community experiences with Project RISHTA: A youth empowerment program to delay marriage in Jharkhand, India. Center on Gender Equity and Health, University of California; 2017. Accessed May 18, 2021. https://gehw eb.ucsd.edu/wp-content/uploads/2019/10/packard-pr oject-rishta-final.pdf.

34. Nanda P, Datta N, Das P. Impact on marriage: Program assessment of conditional cash transfers. International Center for Research on Women; 2014. Accessed October 11, 2018. https://www.icrw.org/wpcontent/uploads/2016/10/IMPACCT Hires FINAL 32 $\underline{0 . p d f}$

35. Nanda P, Das P, Datta N, Lamba S. Making change with cash? Impact of a conditional cash transfer program on age of marriage in India. International Center for Research on Women; 2016. Accessed February 28, 2021. https://www.icrw.org/wp-content/ uploads/2016/10/IMPACCT_ProcessBrief_Webready.pd $\underline{f}$ 
36. Sambodhi Research and Communications Pvt. Ltd. Evaluation of empowering young girls and women in Maharashtra, India. UNICEF; 2019. Accessed May 18, 2021. https://www.unicef.org/evaluation/reports\#/det ail/103/evaluation-of-empowering-young-girls-andwomen-in-maharashtra-india

37. Zibani NI. Ishraq (Sunrise) program in rural Upper-Egypt. In: Sewall-Menon J, Bruce J, eds. The cost of reaching the most disadvantaged girls: programmatic evidence from Egypt, Ethiopia, Guatemala, Kenya, South Africa, and Uganda. Population Council; 2012:23-32. Accessed August 3, 2018. http://www.popcouncil.org/uploads/pdfs/2012P GY_CostOfReachingGirls.pdf

38. Sewall-Menon J, Bruce J. The cost of reaching the most disadvantaged girls: Programmatic evidence from Egypt, Ethiopia, Guatemala, Kenya, South Africa and Uganda. Population Council; 2012. Accessed September 28, 2017. https://www.popcouncil.org/uplo ads/pdfs/2012PGY_CostOfReachingGirls.pdf

39. Brady M, Assaad R, Ibrahim B, Salem A, Salem E, Zibani NI. Providing new opportunities to adolescent girls in socially conservative settings: The Ishraq program in rural Upper Egypt. Population Council; 2007. Accessed August 3, 2018. https://pdfs.semantics cholar.org/fa90/f24486aaf15be15d5444bf5f2ff5072f0d 22.pdf

40. Erulkar AS, Muthengi E. Evaluation of Berhane Hewan: A program to delay child marriage in rural Ethiopia. Intl Perspect Sex Reprod Health. 2009;35(1):6-14. doi:10.1363/3500609

\section{Erulkar A. Building an evidence base to delay} marriage in sub-Saharan Africa. Population Council; 2014. Accessed August 3, 2018. http://www.popcounci l.org/research/building-an-evidence-base-to-delay-m arriage-in-sub-saharan-africa

42. Catino J, Colom A, Del Valle A. Abriendo Oportunidades in Guatemala. In: Sewall-Menon J, Bruce J, eds. The cost of reaching the most disadvantaged girls: programmatic evidence from Egypt, Ethiopia, Guatemala, Kenya, South Africa, and Uganda. Population Council; 2012:41-48. Accessed August 3, 2018. http://www.popcouncil.org/uploads/pdfs/2012P GY_CostOfReachingGirls.pdf

43. Snilstveit B, Stevenson J, Phillips D, et al. Interventions for improving learning outcomes and access to education in low- and middle-income countries: A systematic review. 3ie Systematic Review 24. International Initiative for Impact Evaluation (3ie); 2015. Accessed May 18, 2021. https://www.edulinks.org/sites/default/files/media/file/Intervention s\%20for\%20improving\%20learning\%20incomes\%20a nd\%20access\%20to\%20education\%20in\%20LMICs.pd f
44. Karan A, Kumar R, Sheehan P, Rasmussen B. Education interventions in India. Victoria Institute of Strategic Economic Studies, Victoria University; 2020.

45. UNICEF. Global databases: Child marriage.; 2018. Accessed October 11, 2018. https://data.unicef.org/to pic/child-protection/child-marriage/

46. World Bank. Poverty and shared prosperity 2020: Reversals of fortune. International Bank for Reconstruction and Development; 2020. Accessed April 23, 2021. https://www.worldbank.org/en/publica tion/poverty-and-shared-prosperity\#: :text=Now\%2 C\%20the\%20COVID\%2D19\%20(,into\%20extreme\%20 poverty\%20in\%202020

47. Kochhar R. The pandemic stalls growth in the global middle class, pushes poverty up sharply. Pew Research Center; 2021. Accessed April 23, 2021. https://www.p ewresearch.org/global/2021/03/18/the-pandemic-stall s-growth-in-the-global-middle-class-pushes-povert y-up-sharply/

48. Ministry of Statistics and Programme Implementation (MOSPI). Annual and quarterly estimates of GDP at constant prices, 2011-12 series. Government of India; 2021. Accessed April 23, 2021. $\underline{\text { h }}$ ttp://www.mospi.nic.in/data

49. Paul P. Effects of education and poverty on the prevalence of girl child marriage in India: A district-level analysis. Child Youth Serv Rev. 2019;100:16-21. doi:10.1016/i.childyouth.2019.02.03 3

50. Marcouiller D, Ruiz de Castilla V, Woodruff C. Formal measures of the informal-sector wage gap in Mexico, El Salvador, and Peru. Econ Dev Cult Change. 1997;45(2):367-392. doi:10.1086/452278

51. Pagan JA, Tijerina-Guajardo JA. Increasing wage dispersion and the changes in relative employment and wages in Mexico's urban informal sector: 1987-1993. Appl Econ. 2000;32(3):335-347. doi:10.108 $\underline{0 / 000368400322769}$

52. Packard G. Do workers in Chile choose informal employment? A dynamic analysis of sector choice. World Bank Research Policy Paper 4232. World Bank; 2007. Accessed April 27, 2021. https://openknowledge.world bank.org/handle/10986/7121

53. Arias O, Khamis M. Comparative advantage, segmentation and informal earnings: a marginal treatment effects approach. IZA DP No. 3916. Institute for the Study of Labor; 2008. Accessed April 27, 2021. http://ftp.iza.org/dp3916.pdf 
54. Tegoum N. Estimating the returns to education in Cameroon informal sector. Presented at: GLOBELICS 2009, 7th International Conference, 6-8 October 2009; Dakar, Senegal. Accessed May 19, 2021. http s://smartech.gatech.edu/handle/1853/34894

55. Raj A, Saggurti N, Balaiah D, Silverman JG. Prevalence of child marriage and its effect on fertility and fertility-control outcomes of young women in India: A cross-sectional, observational study. Lancet. 2009;373(9678):1883-1889. doi:10.1016/s0140-6736(0 9)60246-4

56. Hallman K, Roca E. Reducing the social exclusion of girls. Population Council; 2007. Accessed September 27, 2017. http://www.popcouncil.org/uploads/pdfs/TA Briefs/PGY_Brief27_SocialExclusion.pdf

57. Delprato M, Akyeampong K, Dunne M.

Intergenerational education effects of early marriage in sub-Saharan Africa. World Dev.

2017;91(1):173-192. doi:10.1016/j.worlddev.2016.11.0 $\underline{10}$
58. UNFPA. State of the world population: Against my will. UNFPA; 2020. Accessed February 25, 2021. http s://www.unfpa.org/swop

59. UNFPA. Impact of the COVID-19 pandemic on family planning and ending gender-based violence, female genital mutilation and child marriage. Interim Technical Note. UNFPA; 2020. Accessed April 27, 2021. https://www.unfpa.org/sites/default/files/resource-pd f/COVID-19 impact brief for UNFPA 24 April 202 01.pdf

60. Banerjee AV, Duflo E, Kremer M. The influence of randomized controlled trials on development economics research and on development policy. Paper prepared for Conference proceedings: the state of economics, the state of the world. World Bank; 2016. Accessed February 25, 2021. https://scholar.harvard.edu/files/k remer/files/the-influence-of-rcts-on-developmentaleconomics-research-and-development-policy.pdf

61. Banerjee AV, Duflo E. The experimental approach to development economics. Annu Rev Econom. 2009;1(1):151-178. doi:10.1146/annurev.economics.0 $\underline{50708.143235}$ 